\title{
Beginning with Hermes
}

\section{Promoting Hermeticism through Aetiology in Corpus Hermeticum 1}

\author{
Sean E. McGrath
}

\section{1 \\ Introduction ${ }^{1}$}

The Roman imperial period saw the flourishing of a great variety of new deities, cults and other types of religious movements. The question how to promote a new cult in the face of the large existing competition was therefore quite relevant for their followers. One of the techniques that can be applied for its promotion, as I show in this contribution with respect to Hermeticism, was the construction of an appropriate aetiology. In the first treatise of the Corpus Hermeticum, a movement bordering between religion and philosophy applied aetiological motifs to appropriate ideas from Greek philosophy and create a sense of 'common ground' meant to attract Jewish followers.

Hermeticism originated in the Hellenistic period, during which the Kingdoms founded in the wake of Alexander's conquests facilitated cultural exchange between Greeks and various other cultures around the Eastern Mediterranean. Greek thought and myth had always drawn much inspiration from eastern cultures, ${ }^{2}$ and the enduring intercultural contact in the Hellenistic kingdoms provided new impulses for religious syncretism. During this time, many local gods were imported into other regions, a process which continued in the imperial period. For instance, Isis and Serapis, respectively an Egyptian goddess and a god who was a syncretistic mixture of Egyptian and Greek elements created by the Ptolemaic dynasty, were revered throughout the Roman world. Some other religious movements, such as Gnosticism, were heavily influenced by contemporary philosophy. This also applies to Hellenistic Judaism and, somewhat later on, early Christianity. ${ }^{3}$ Many of these

1 I would like to thank the editors, especially Jacqueline Klooster, and the reviewer for their many helpful suggestions that significantly improved the quality of this contribution, as well as Alexandra Madeła for her help with linguistic issues.

2 See e.g. West 1997; Haubold 2013; Bachvarova 2016.

3 For the influence of Hellenistic philosophy on contemporary Judaism, see for instance Niehoff 2013. For the role of Greek philosophy on early Christianity see, among others, Rasimus, Engberg-Pedersen and Dunderberg 2010 and Rist 1985, on Christian Platonism. 
new religious movements can be considered the results of interaction between the Greco-Roman Leitkultur and regional elements, the products of cultural contacts on an unprecedented scale for this region.

Among this multitude of religious novelties we place the cult of Hermes Trismegistus, Hermeticism, which must certainly be reckoned as one of the Hellenistic cults with the longest Nachleben. The figure of Hermes captivated not only his original followers from Ptolemaic and Roman Egypt but also reached the Christian and Islamic world in the medieval era and saw a revival during the Renaissance. ${ }^{4}$ This raises the question how we can account for the success of specifically this religious tradition vis-à-vis other cults of similar character which did not survive antiquity.

One advantageous factor for its survival is that Hermeticism was successfully re-appropriated by Christian intellectuals in late antiquity: Hermes was considered a prophet of Christ, and Christian authors approvingly quoted Hermetic texts. ${ }^{5}$ Yet even before that, there are about four centuries between the earliest signs of life of the cult from the Ptolemaic period ${ }^{6}$ and discussions of Hermeticism by Christian writers. There must have been numerous reasons for the enduring popularity of Hermeticism throughout the imperial era. One of these is Hermeticism's ability to legitimate itself through the (apparently successful) utilization of aetiological topoi and invented traditions. The cult of Hermes Trismegistus, in reality a result of the synthesis of Greek and Egyptian deities in the Hellenistic period, presents itself as a much more ancient tradition, based on archaic Egyptian prophecies, a factor which seems intended to contribute to its prestige.

After a short introduction on Hermeticism and the social milieu in which it flourished, I demonstrate how reading the first treatise of the Corpus Hermeticum through the lens of aetiology can elucidate the techniques used to promote Hermeticism. This treatise, known as Poimandres, provides an account of the creation of the physical world, containing elements from Greek, especially Platonic, philosophy and from the Jewish creation myth from the Biblical book of Genesis.

4 Ebeling 2007 provides an overview of Hermeticism until the modern era. Van den Broek and Hanegraaff 1998 contains articles on the reception of Hermeticism after antiquity. On the later history of the Corpus Hermeticum until the present day see also Copenhaver 1992, xlv-lix.

5 This was especially the case in Lactantius, but also in other early Christian authors, as Fowden 1986, 205-210 demonstrates.

6 The existence of at least the magical branch of Hermeticism in the Ptolemaic period is affirmed by Fowden 1986, 2. 
First, I discuss how the motif of the 'first inventor' is employed to claim an authoritative position for the Hermetic texts: Hermetic literature asserts that its founder is the source of much of Greek wisdom, while in reality it is an outcome of the Greek intellectual tradition. By positing Hermes as the first to express many Greek ideas and presenting him as the teacher of leading Greek thinkers, his followers attempted to appropriate fundamental concepts from Hellenistic philosophy.

Secondly, I argue that the appropriation of aetiological tropes from the Jewish account of creation (as found in Genesis) serves as an 'anchor' to make Hermeticism accessible to a Jewish audience. Anchoring describes the process in which innovations are related to previously known objects or ideas in order to make these novelties acceptable to a community. If an innovation is successfully anchored in a common ground, it is more likely to be accepted and adopted. ${ }^{7}$ I argue that similar mechanisms are in play in the case of the Poimandres: it is not philosophically necessary that the creation of the world in the Hermetic creation account must resemble that of the book of Genesis. Instead, the overlap functions as a means to attract a Jewish readership to the cult of Hermes.

The origins of Hermeticism are not entirely clear. Yet despite the absence of any definitive evidence, the current scholarly consensus is that Hermeticism has its roots in Ptolemaic Egypt, where the Greek god Hermes was assimilated with the Egyptian deity Thoth. ${ }^{8}$ Aside from some changes in the worship of these two traditional gods, this led to the emergence of a new figure known as Hermes Trismegistus, who was more than simply the sum of the titles and domains of these two deities. This new Hermes became known as an Egyptian prophet who had endowed mankind with philosophical and theological wisdom, and who was often cited among other human authorities. Yet all extant Hermetic literature remains (deliberately?) vague on the exact ontological status of its ultimate source; refusing to state whether he is merely an enlightened human or has some share in the divine in his own right. He is, in any case,

7 Cf. the introduction and Annette Harder's chapter in this volume.

8 Greek and Egyptian gods had, however, already been compared with each other since at least Herodotus. In Hist. 2.67 he seems to imply that Hermes and Thoth are the same deity: he claims that the ibis was sacred in a city he calls Hermopolis, which was the Greek name for Khemenu, the main cult center of Thoth. 
distinguished from the gods Hermes and Thoth from which he is derived, ${ }^{9}$ being instead presented as a sage who conversed with the gods at an undefined period in the past. ${ }^{10}$

The story propounded in some texts of the Corpus Hermeticum is that Hermes Trismegistus is an ancient Egyptian figure whose mystical prophecies have been translated into Greek." Several of these texts, philosophical and/ or religious in character, have come down to us. First of all, there is the Greek Corpus Hermeticum. An originally Greek treatise has also reached us in Latin translation under the name of Asclepius; the Greek title was most likely Teleios logos. There are also some fragments of Hermetic texts quoted by other ancient and medieval authors. Finally, our corpus has been enriched in 1945 with the discovery of the Nag Hammadi library, in which (among mostly Gnostic texts) three Hermetic treatises were found, written in Coptic. ${ }^{12}$

These texts contain a doctrine that is not entirely consistent throughout the corpus, but the main tenet of Hermeticism is clearly based upon a dualism between the material body and the immaterial soul. Hermes is said to have taught his followers to abandon and transcend the mortal body. By doing so, one could reach a higher plane of existence and achieve a state of immortality and divinity instead of perishing as a human. ${ }^{13}$

Despite the insistence in the Corpus that Hermetic literature was composed by an ancient Egyptian sage in the remote past, the textual evidence suggests something different. The Hermetic texts are the product of a multicultural environment from a later point in history. ${ }^{14}$ Their doctrine derives from Greek philosophy, especially from (middle) Platonism and Stoicism, yet some Egyptian

9 Such as in Ps.-Manetho, quoted by Syncellus p. 72 (as published in Waddell 1940, 208-211), but also in Ascl. 37 .

$10 \quad$ Fowden 1986, 23sq., 27sq.; Ebeling 2007, 13.

11 See for instance Iamb. Myst. 8.4, who argues that any resemblances to philosophical concepts from the Greek tradition are the result of the translator's efforts. Within the corpus, this is implied most emphatically in Corp.Herm. 16.1-2, in which Asclepius warns Ammon not to allow the Greeks to translate these texts into their own language. Fowden 1986, 37 suggests that this passage in fact reflects contemporary tensions between Egyptians and Greeks at the time it was written. Ebeling 2007, 25 sees this as a method to justify errors, as their true meaning would be obscured by the process of translation.

12 A more elaborate survey of extant Hermetic literature is given by Ebeling 2007, 15. Aside from these philosophical texts, there are texts which are referred to as the technical Hermetica, dealing with topics such as alchemy, astrology and magic. These technical works will not be discussed in this chapter.

13 This doctrine is taught in the case of the Poimandres in Corp.Herm.1.21-26.

14 Denzey 2013, 104 has the most complete and up-to-date bibliography regarding the various cultural influences on the Hermetic texts. 
deities belong to their main cast, ${ }^{15}$ and they also draw from the Septuagint. ${ }^{16}$ The texts have been broadly dated to the first centuries of the Common Era, but a number of factors make a definitive chronology difficult. First of all, the Corpus does not distinguish between individual authors; all texts are simply ascribed to the pseudepigraphical author Hermes. In reality, they were most likely revised by later writers, and it is impossible to identify the various layers of composition. Some texts refer to other treatises in the Corpus, which means that their author(s) was/were familiar with other Hermetic literature and write(s) in reaction to this. ${ }^{17}$ The individual texts were, therefore, not part of a single body of texts; collection must have occurred at a later date. ${ }^{18}$ Additional problems are caused by the many textual corruptions within the Corpus. ${ }^{19}$

Hermeticism most likely originated in the urban centers of Egypt. As Gareth Fowden argues, the city of Alexandria provided an especially fertile environment for the cultural contact and syncretism that characterizes extant Hermetic literature. From there, this new Hermes spread to other parts of Northern Africa and the eastern half of the Empire, while remaining popular in Egypt - Hermeticism never grew quite as popular in the west. ${ }^{20}$ Material culture related to this cult is conspicuously absent. To our knowledge, no temples for Hermes Trismegistus exist, nor other ritual items such as statues or figurines. We know, therefore, very little about cultic practices and are entirely dependent on the literary accounts that have been transmitted.

But why would cult practitioners in Alexandria and other Egyptian cities claim that their Hermes Trismegistus was specifically an ancient Egyptian, and that their cult writings were translations of an originally Egyptian text? The most likely answer to this question lies in the prestige that Egypt enjoyed among Greeks. They generally admired the antiquity of Egypt, despite their insistence on the great cultural differences. Numerous accounts cast important Greek thinkers like Solon, Pythagoras and Plato as visitors to Egypt, having

15 The most noteworthy are some of the characters that appear in Hermetic literature, especially Tat (a Hellenized spelling of Thoth), but also e.g. Isis and Ammon. The title Trismegistus ('thrice greatest') itself is Egyptian in origin, but first occurs during the Hellenistic era, applied to Thoth (cf. Copenhaver 1992, 93). The epithet resembles its precedents in Egyptian religion.

16 The relationship between the Corpus Hermeticum and the Septuagint is highlighted by Pearson 1981 and Dodd 1954.

17 Fowden 1986, 187 discusses the issue of anonymous authorship.

18 On the collection of the Hermetic literature, see Copenhaver 1992, xl-xlv.

19 See Wildberg 2013 for a philological survey of the Corpus Hermeticum, especially of Corp.Herm. 3 .

20 On the Alexandrian origin, see Fowden 1986, 162, 193 and passim, and 196-198 for Hermeticism outside Egypt. 
been taught ancient Egyptian wisdom by the local priests. ${ }^{21}$ In such a context, one could hardly imagine a more authoritative source of religious truth than the prophecies of an archaic Egyptian sage in direct contact with divine beings. The Egyptian connection could therefore serve to legitimate the cult. Yet Hermes's followers went even further: as we shall see, they did not only portray their Hermes as a figure from the remote past, but also presented him as the source of all subsequent Greek wisdom.

\section{$3 \quad$ Appropriating Greek Philosophy}

Many Greek thinkers are fascinated by the aetiological motif of the first inventor. Deities and other mythological characters are often credited with technical and intellectual innovations. ${ }^{22}$ We also, however, encounter the opposite pattern: developments in historical times could be attributed, retrospectively, to mythical figures. For instance, Maren Niehoff argues that Flavius Josephus presents the Jewish patriarch Abraham as the first to devise a monotheistic creation in terms that would be familiar to a Stoic audience. She writes as follows about Jewish Antiquities $1.155^{-156:}$

Josephus' Abraham clearly thinks here in terms of Stoic Nature theology. Like Chrysippus and his followers, he infers one divine power from the beneficial organization of the cosmos, which he identifies with the creator. [...] Josephus' language is highly competitive. His Abraham was the

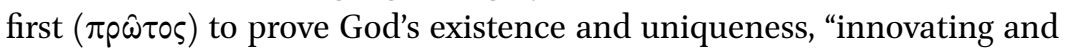
dramatically changing the universally held conception concerning God." The Jewish religion thus emerges not only as compatible with rational theology, but as its very cradle. ${ }^{23}$

With this practice of appropriation, Josephus is in fact rewriting intellectual history: he claims that the Stoic concepts of divinity and creation are posterior to or even derived from Judaism, i.e., that the Jews had developed these ideas long before the Stoics. According to Niehoff, this passage is Josephus's

21 For Solon see briefly Hdt. 1.29 and the much more elaborate account in Pl. Ti. 21c-25d. Pythagoras' visit to Egypt is mentioned in numerous sources, such as Hdt. 2.81, Isoc. 11.28, D.L. 8.1.3. For Plato see Str. 17.1.29, D.L. 3.6. This topos of a trip to Egypt is also discussed by Ebeling 2007, 25 .

22 On this topic, see also the chapters by Inger Kuin and Hugo Koning in this volume.

23 Niehoff 2013, 104; cf. also p. 98, in which she demonstrates that Philo of Alexandria makes the same argument (but less elaborately than Josephus). 
legitimation of his religion to a Hellenic and Roman readership, in order to make them appreciate the antiquity and wisdom held by the Jewish people.

The adherents of Hermeticism similarly attempt to appropriate elements of the intellectual culture they were raised in. This will become evident from an examination of the first and most discussed treatise of the Corpus Hermeticum, known as the Poimandres. It tells us how an androgynous deity, Poimandres, taught Hermes ${ }^{24}$ the true nature of the world and the way to attain salvation from death, which relies on knowledge received through revelation. Most of the Poimandres is structured in the form of a dialogue between Hermes and Poimandres in which Poimandres answers Hermes's questions, a format that might find its origins in the invocations of, and later dialogues with, the Muses from Greek poetry. ${ }^{25}$ The Poimandres begins as follows:

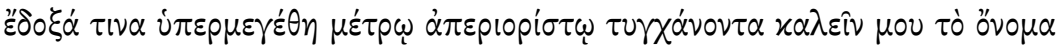

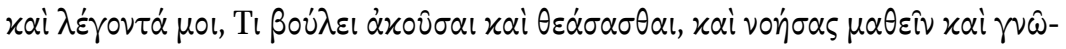

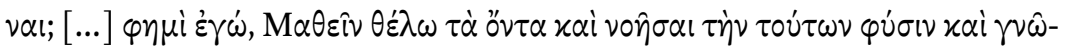

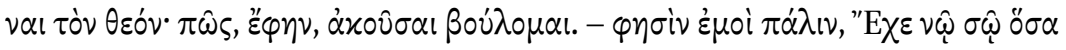

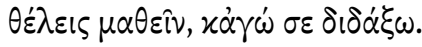

Corp.Herm. 1.1-3

An enormous being, completely unbounded in size, seemed to appear to me and call my name and say to me: "What do you want to hear and see; what do you want to learn and know from your understanding?" [...] I said, "I wish to learn about the things that are, to understand their nature and to know god. How much," I said, "I want to hear!" Then he said to me: "Keep in mind all that you wish to learn, and I will teach you." ${ }^{26}$

Poimandres subsequently shows Hermes a vision which Hermes does not understand and provides an interpretation in the form of an account of the creation of the physical world. The revelation about the nature of things and of god are in part derived from (middle) Platonism, with a significant portion of the Poimandres's cosmology echoing Plato's Timaeus. ${ }^{27}$

24 Although Hermes's name is not mentioned in the text itself, later Hermetic literature alludes to the Poimandres and clearly indicates that its speaker is Hermes. Cf. Copenhaver 1992, 94 with the relevant bibliography on this topic.

25 Important models of this type are Hes. Th. 21-35 and Call. Aet. fr. 2 Harder.

26 The Greek text of the Corpus Hermeticum is taken from Nock and Festugière 1945-1954. All translations are by Copenhaver 1992.

27 For a more thorough exploration of the Platonic influences in Corp.Herm. 1 see the commentary by Copenhaver 1992, passim; also Denzey 2013, 114-117. 
This debt to the Timaeus is visible at the start of Poimandres's account of creation (Corp.Herm. 1.9-11). In the beginning, the intellect (vov̂s), which is also known as father and god ( $\pi \alpha \tau \dot{\eta} \rho \theta \varepsilon o ́ \varsigma, 1.6)$, gives birth to a second god, a

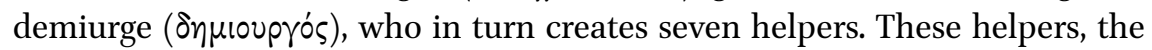
planets, encompass the sensible world and are collectively known as 'fate'

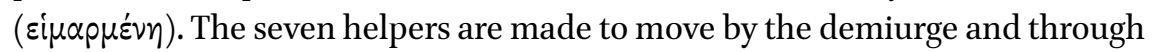
their revolution all living beings are created from the four elements. The concept of a demiurge is derived from Plato's Timaeus, according to which the physical world was crafted from extant matter by an intelligent creator-god. Furthermore, the influence of later strands of Platonic thought can also be distinguished. For instance, the relationship between intellect and demiurge is strikingly similar to Numenius's theology. Numenius also distinguishes a first god, the intellect (vovs) who is also called the father, from a creator god, the demiurge, who produced the cosmos. This demiurge is analogous to the intellect and called its imitator. ${ }^{28}$

The creator-god is not the only striking influence of the Platonic tradition. The Hermetic theory of salvation as explored in the Poimandres draws heavily on the Platonic dualism of an immortal soul in opposition to the transient body. Hermes learns from Poimandres that if we actively choose to transcend the material world, we can reach the upper realms and become gods ourselves and thereby achieve freedom from death and decay. Furthermore, Nicola Denzey has demonstrated how developments in Middle Platonism also appear in the Poimandres and other Hermetic literature; specifically, a negative evaluation of the material world (cosmic pessimism) and the view that the cosmos is complex, multi-layered, populated with malevolent demons in the lower realms (demonology), with different forces of fate located in different regions. ${ }^{29}$ For instance, in Corp.Herm. 1.22-23, Poimandres states that they, the intellect, only grant the pious, good, and pure a share of intellect and access to the higher realms, while they entrust the evildoers to a vengeful demon $(\delta \alpha i \mu \omega \nu)$. Another typical feature of earlier imperial Platonism is the association of the planets with specific vices. This idea looms in the background in Poimandres's instructions for transcending the body, which involves abandoning various vices in seven stages, which correspond to the seven planets. ${ }^{30}$

A thorough investigation of the various philosophical influences on the Poimandres lies outside of the scope of this chapter, but I hope to have given

28 Copenhaver 1992, 104 states that the idea that the demiurge came forth as a second god from the intellect is also found in many middle Platonic texts.

29 Denzey 2013.

30 Denzey 2013, 114sq. 
an impression of the tradition against which we should read this treatise. Centuries of Greek thought are reflected by the revelation of the Hermetic deity Poimandres, ${ }^{31}$ and Hermes is cast as the first human to learn the nature of the universe. He is subsequently sent out by Poimandres to spread the truth among his fellow men (Corp.Herm. 1.27):

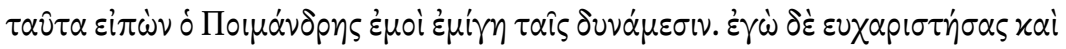

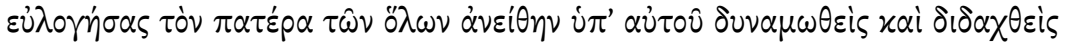

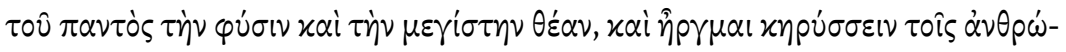

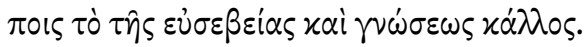

As he was saying this to me, Poimandres joined with the powers. Then he sent me forth, empowered and instructed on the nature of the universe and on the supreme vision, after I had given thanks to the father of all and praised him. And I began proclaiming to mankind the beauty of reverence and knowledge.

Hermes may also be claiming that he preserved the revelation in written form. The Greek is ambiguous, literally meaning 'I have recorded Poimandres'

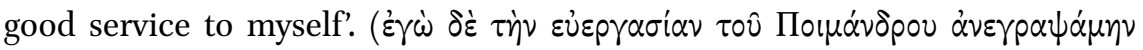

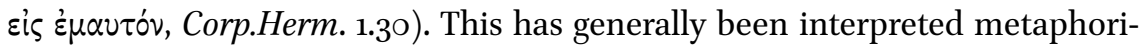
cally: "Within myself I recorded the kindness of Poimandres" (Copenhaver), "I inscribed in my memory" (Scott), "Pour moi, je gravai en moi-même" (Festugière). I am, however, not aware of another instance of a similar use of $\alpha v \alpha \gamma p \alpha \dot{\varphi} \omega \omega$. Festugière and Nock acknowledge that this remark can also be taken in a literal sense: "Mais peut-être: 'J'enregistrai par écrit pour moi-même"” ('I recorded it in writing for myself'). ${ }^{32}$ Perhaps the best way to make sense of

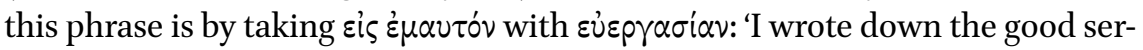
vice Poimandres conferred on me.' With that interpretation, the very treatise we are reading is Hermes' own account of Poimandres's revelation.

Hermes is in any case considered to be responsible for the circulation of Poimandres's creation account among mortals, and the treatise thereby implicitly provides an origin for all other Hermetic writings as well as major strands of the Greco-Roman philosophical tradition. In Hermetic chronology, these

31 Poimandres does not occur outside of Hermetic literature and even within Hermeticism they remain an obscure figure. It is tempting to see their name as a derivation of the Greek $\pi \circ \mu \alpha i v \omega$ and $\alpha \dot{v} \tilde{\rho}$, but most scholars believe that the name in fact has a Coptic origin. On this issue see especially Scott 1924-1936, vol. 2, 15sq.; also Dodd 1954, 99, n. 1; Copenhaver 1992, 95 .

Nock and Festugière 1945-1954, 1.26. 
revelations occur prior to the development of Greek philosophy and therefore, it is implied, ideas attributed to philosophers such as Plato actually originated from the divine revelations to Hermes.

This raises the question whether the Hermetics succeed in presenting their prophet as founder of a long philosophical tradition. In fact, we have intriguing evidence that this appropriation of philosophical material was indeed quite effective. The followers of Hermes succeeded in convincing later (non-Hermetic) intellectuals that Platonic doctrines had originated from an allegedly primeval prophet. Lactantius, writing in the early fourth century, suggested that Plato was inspired by Hermes Trismegistus (Lact. Epit. 37.4):

denique Plato de primo ac secundo deo non plane ut philosophus, sed ut uates locutus est, fortasse in hoc Trismegistum secutus

Plato, then, clearly does not speak about the first and the second god as a philosopher but like a prophet, maybe following Trismegistus in this. ${ }^{33}$

Within one century of Lactantius' careful suggestion (fortasse) that Plato might have been following Hermes, Proclus stated in his fifth-century commentary on Plato's Timaeus that Plato most likely drew on Hermetic literature (Proc. In Ti. 2.386 = Iamb. fr. 38 Dillon):

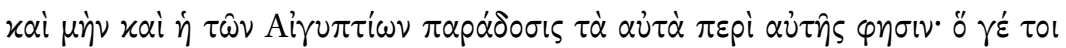

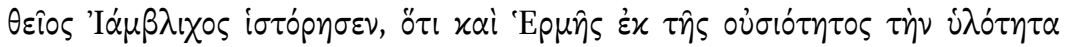

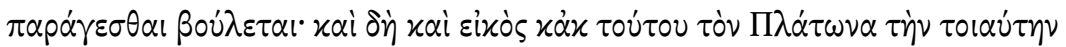

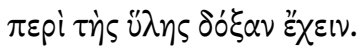

And indeed Egyptian tradition also says the same about [matter]. At any rate, the divine Iamblichus reported that Hermes, too, wants materiality to be derived from substantiality. And in fact it is even likely, [he adds,] that Plato gets this kind of view of matter from [Hermes] as well. ${ }^{34}$

With his allusion to Iamblichus, we get the impression that Proclus follows a well-established tradition in which Plato had been inspired by Hermes. ${ }^{35}$

33 The translation of this passage is my own.

34 The translation of this passage is taken from Runia and Share 2008.

35 Dillon 1973, 312sq. argues that the passage Proclus is quoting is most likely taken from Iamblichus' commentary on the Timaeus. Notably, similar ideas were even held well into the Renaissance, as Marsilio Ficino believed that Hermes had taught Pythagoras during 
Neither of the authors places any doubt in Hermes's antiquity and the relative chronology of these two authorities. At some point during the early imperial period, Hermetic thinkers had placed their prophet at the very beginning of Greek philosophy and argued that many subsequent thinkers were in fact drawing on Hermes and therefore on Egyptian wisdom as the source of their ideas.

We have already seen how the Hermetic account of the creation of the universe was heavily influenced by the Platonic tradition. Yet there is another crucial influence in the Poimandres, namely the Biblical creation story of Genesis 1.1-2.3. The author of this treatise must have been familiar with the Greek translation of the Hebrew Bible, the Septuagint. Dodd especially demonstrated how closely the two texts are related and that much of the terminology employed in the Poimandres is taken from the Septuagint. ${ }^{36}$ Yet Biblical influence is not limited to the lexical level: the process of creation itself takes place in the Poimandres in almost exactly the same order as during the first six days of Genesis. The order is identical except that the separation of land and water, which took place on the third day of the Biblical account, is not described in the Poimandres. ${ }^{37}$ On the other hand, typical features from creation myths of other cultures are absent, making the Jewish element in this text all the more striking. ${ }^{38}$

We could then classify the Poimandres as an adaption of Greek philosophy against the backdrop of Hebrew myth, which is presented as the revelation of an ancient Egyptian sage. This package of multicultural influences reflects the milieu in which the Poimandres was written and more broadly the environment in which the Hermetics operated. Yet the Poimandres is not a mirror reflecting the mixed character of urban society of early imperial Egypt. Each of

his stay in Egypt, through whom these teachings were transmitted to Plato (see Iversen 1984, 27).

36 Dodd 1954, 107. On the Jewish influence on the Poimandres's vocabulary see also Pearson 1981, 340sq.

37 Dodd 1954, 103: "apparently he omitted it, either through inadvertence, or because he wished the creation of the heavenly bodies to follow immediately upon the separation of the upper and lower elements."

38 Dodd 1954, 100-103. Of course, Genesis itself also drew on earlier sources. I am, however, unable to pursue the question of common sources or further intermediaries between Poimandres and Genesis in the limited scope of this survey. See n. 2, above, on other cultural interactions between Greek and Eastern literature. 
the three cultural influences present in the treatise is limited to certain aspects of the text and remains unaffected by the other sources.

The presence of Egyptian culture in the Poimandres is rather limited. Except for the names of Hermes Trismegistus and Poimandres, both of which have Egyptian roots, ${ }^{39}$ there are only little traces of actual Egyptian influences in the intellectual framework. ${ }^{40}$ This seems to be informed almost entirely by the Greek tradition, although Pearson does assert that the Poimandres has some similarities with Jewish apocalyptic literature. ${ }^{41}$ The Septuagint contributes mostly to the style of the text, ${ }^{42}$ as well as supplying the structural model for the creation myth. The doctrine itself, however, does not necessitate influences outside of Greek tradition. In other words, we are not dealing with a cross-cultural mixture of philosophical systems but rather with an essentially Greek core surrounded by Jewish and to a lesser degree Egyptian flavouring.

So why do Genesis and Jewish literature more broadly feature so conspicuously in the Poimandres, if they do not substantially influence the doctrine this treatise presents? One way to interpret the Jewish elements in the Poimandres is through the concept of 'anchoring'. The creation account of the Poimandres can be approached as a conceptual anchor to create common ground for a Jewish audience in order for them to identify with the cult of Hermes Trismegistus more easily. The Jewish reader would have no problem recognizing the creation of the world of this Hermetic text with what he or she is already familiar with from Hebrew scripture. But why would the authors of the Poimandres aim to cater specifically for potential Jewish followers? Pearson has argued that, due to the political tensions of the first and second century, Judaism had become less fashionable in comparison to other philosophical and religious movements during the early Empire. ${ }^{43}$ The Jews were therefore, in the eyes of Hermetics at least, a desirable target audience, providing a large pool of people who could potentially be converted to Hermeticism.

39 Cf. n. 15 on the title Trismegistus and n. 31 on Poimandres.

40 Iversen 1984, 29-33 argues for the influence of Egyptian theology on the Hermetic texts and gives numerous parallels between the two. Many of his examples, however, can just as easily and in my opinion more plausibly be ascribed to the Platonic tradition, for instance the two entities of the creator and demiurge (although the androgynous nature of both the Egyptian and Hermetic creator is striking), or Jewish influences, such as the creation of the world from a watery darkness.

41 Pearson 1981, 339.

42 This does not mean that the form of the text is not influenced by Greek models. Nock 1972 has argued that Corp.Herm. 1 is also influenced in form by the diatribe, a popular type of literature in the imperial period.

43 Pearson 1981, 347sq. 
The beginning of Genesis, that is to say, the creation of the physical world, is especially suitable for this purpose. A common origin suggests that, fundamentally, Jews and Hermetics inhabit the same world. In this case, aetiology in the sense of a creation story functions as a means of connecting diverse communities. Jews could more easily assimilate to a religious movement essentially based on Greek philosophy because it did not require a radically different outlook on the world. They could map the tenets of Hermes onto the world as they knew it. Perhaps the Hermetics even attempted to argue that becoming a follower of Hermes was not a binary choice between one and the other, as both traditions ultimately derive from a common source.

Unfortunately, we have no evidence whether this strategy was actually successful. We have no way of knowing whether Jews indeed converted to Hermeticism or, perhaps more likely, whether they thought it possible to be both a Jew and a Hermetic (although this attempt to create common ground suggests that the Hermetics did not consider these two as mutually exclusive). Lactantius did not find it problematic to follow the teachings of Hermes as a Christian, so perhaps the prophet Hermes Trismegistus could also have been considered complementary to the prophets found in the Hebrew Bible.

On the other hand, the attempt to convert Jews may have failed miserably, after which the idea was given up. This may explain why the Poimandres contains significantly more Jewish influences than most of the other Hermetic texts, which may have been written at a later point in time. The followers of Hermeticism may have underestimated the value Jews placed on their descent and not their religion as the denominator for their collective identity.

\section{5 Conclusion}

In this chapter I have argued that we can receive greater insight in the social function of the Corpus Hermeticum's first treatise by approaching it through the lens of aetiological discourse. Aetiology can be employed both as a means to highlight the inclusivity of a certain group and as a form of competition in which various traditions make claims as to be the anterior source of a certain idea or concept and thereby vie for a form of cultural prestige. Both of these purposes are present in the Poimandres simultaneously, yet each is aimed at a different target audience.

Platonic philosophy belonged to the dominant currents of Greco-Roman intellectual culture and therefore, a relatively marginal and initially regional religious movement needed to demonstrate its respective merits vis-à-vis the more mainstream religious and philosophical traditions. The Poimandres's 
attempt to distinguish itself does not differ radically from the model of cultural competition in the writings of leading Jewish intellectuals of the early imperial period. One of the Hermetics' means to achieve a unique standing among the multitude of contemporary religious movements was to position their prophet as a first founder on whose revelations consecutive Greek thinkers ultimately relied. Hermes Trismegistus was turned into an ancient, authoritative figure and thereby, his cult could claim to be the primary source of spiritual truths.

As a consequence, Hermetics succeeded in imagining an origin of the world which coincides with that of Jewish scripture. They employed aetiology as a means to forge, in retrospect, a connection between two historically unrelated cultures. Through their endorsement and adoption of the creation account from the book of Genesis, the followers of Hermes sought to diminish the relative differences between themselves and the Jewish people.

\section{Bibliography}

Bachvarova, M.R. (2016). From Hittite to Homer. The Anatolian Background of Ancient Greek Epic. Cambridge: Cambridge University Press.

Copenhaver, B. (1992). Hermetica. The Greek Corpus Hermeticum and the Latin Asclepius in a new English translation, with notes and introduction. Cambridge: Cambridge University Press.

Denzey, N. (2013). Cosmology and Fate in Gnosticism and Graeco-Roman Antiquity. Under Pitiless Skies. Leiden/Boston: Brill.

Dillon, J. (1973). Iamblichi Chalcidensis in Platonis dialogos commentariorum fragmenta. Leiden: Brill.

Dodd, C. (1954). The Bible and the Greeks. 2nd ed. London: Hodder and Stoughton.

Ebeling, F. (2007). The Secret History of Hermes Trismegistus. Hermeticism from Ancient to Modern Times. Ithaca, NY: Cornell University Press.

Fowden, G. (1986). The Egyptian Hermes. A Historical Approach to the Late Pagan Mind. Cambridge: Cambridge University Press.

Haubold, J. (2013). Greece and Macedonia. Dialogues in Literature. Cambridge: Cambridge University Press.

Iversen, E. (1984). Egyptian and Hermetic Doctrine. Copenhagen: Museum Tusculanum Press.

Niehoff, M. (2013). The Emergence of Monotheistic Creation Theology in Hellenistic Judaism. In: L. Jenott and S. Kattan Gribetz, edd., Jewish and Christian Cosmogony in Late Antiquity. Tübingen: Mohr Siebeck, pp. 85-106.

Nock, A. (1972). Diatribe Form in the Hermetica. In: A. Nock and Z. Steward, edd., Essays on Religion and the Ancient World, vol. 1. Cambridge, Mass.: Harvard University Press, pp. 26-32. 
Nock, A. and Festugière, A.-J. (1945-1954). Hermès Trismégiste. Corpus Hermeticum. 3 vols. Paris: Les Belles Lettres.

Pearson, B. (1981). Jewish Elements in the Corpus Hermeticum 1. In: R. van den Broek and H. Vermaseren, edd., Studies in Gnosticism and Hellenistic Religions. Presented to Gilles Quispel on the Occasion of his 65th Birthday. Leiden: Brill, pp. 336-348.

Rasimus, T., Engberg-Pedersen, T. and Dunderberg, I., edd. (2010). Stoicism in Early Christianity. Grand Rapids: Baker Academic.

Rist, J. (1985). Platonism and its Christian Heritage. London: Variorum Reprints.

Runia, D. and Share, M. (2008). Proclus. Commentary on Plato's Timaeus, vol. 2.2: Proclus on the Causes of the Cosmos and its Creation. Cambridge/New York: Cambridge University Press.

Scott, W. (1924-1936). Hermetica. The Ancient Greek and Latin Writings which Contain Religious or Philosophic Teachings Ascribed to Hermes Trismegistus. 4 vols. Oxford: Clarendon Press.

Sluiter, I. (2017). Anchoring Innovation. A Classical Research Agenda. European Review, 25(1), pp. 20-38.

Van den Broek, R. and Hanegraaff, W., edd. (1998). Gnosis and Hermeticism from Antiquity to Modern Times. Albany: State University of New York Press.

Waddell, W. (1940). Manetho. History of Egypt and Other Works. Cambridge, Mass.: Harvard University Press.

West, M.L. (1997). The East Face of Helicon: West Asiatic Elements in Early Poetry and Myth. Oxford: Oxford University Press.

Wildberg, C. (2013). Corpus Hermeticum, Tractate III. The Genesis of a Genesis. In: L. Jenott and S. Gribetz, edd., Jewish and Christian Cosmogony in Late Antiquity. Tübingen: Mohr Siebeck, pp. 139-164. 